\title{
Pengaruh Sikap Keuangan dan Literasi Keuangan Terhadap Perilaku Keuangan Pada Anggota Ghoib Community di Kabupaten Bandung Barat
}

\author{
1Tiani Rahmawati Zakiah, 2Lasmanah, 3Lufthia Sevriana \\ Prodi Manajemen Bisnis, Fakultas Ekonomi dan Bisnis, Universitas Islam \\ Bandung, Indonesia.
}

*1rahmawatianizakiah@gmail.com,2lasmanah.ina@gmail.com, 3lufthia.sevriana@gmail.com

\begin{abstract}
This study aims to analyze the influence of financial attitudes and financial literacy on financial behavior on members of the Ghoib Community in West Bandung Regency. The research method used in this study is the associative method. The data used is primary data through questionnaires and observations using simple random sampling technique. The total population in this study was 185 people, with the sampling using the slovin formula to 65 respondents. Data processing using Statistical Package for Social Science (SPSS) analysis tool with multiple regression analysis method. The results of this study indicate that simultaneously financial attitudes and financial literacy affect the behavior of financial management in members of the Ghoib Community in West Bandung Regency. Simultaneous effect is indicated by the value of fcount $>$ ftable $(38,886$ $>3,15$ ). Partially, financial attitudes have an effect on financial attitudes as indicated by the value of tcount $>$ from ttable $(7.851>1.669)$ while partially financial literacy has no effect on financial attitudes as indicated by the value of tcount $<$ from ttable $(-1.047<1.669)$. R square value of 0.55 indicates that the influence of financial attitudes and financial literacy on financial management behavior is $55 \%$, while the remaining $45 \%$ is influenced by other variables not included in this study.
\end{abstract}

Keywords: Financial Attitudes,Financial Literacy, Financial Management Behavior

Abstrak. Penelitian ini bertujuan untuk menganalisis Pengaruh Sikap Keuangan Dan Literasi Keuangan Terhadap Perilaku Keuangan.Pada Anggota Ghoib Community Di Kabupaten Bandung Barat. Metode penelitian yang digunakan dalam penelitian ini adalah metode asosiatif. Data yang digunakan adalah data primer melalui penyebaran kusioner dan observasi dengan menggunakan teknik simple ramdom sampling. Jumlah populasi dalam penelitian ini sebanyak 185 jiwa, dengan penarikan sampel menggunakan rumus slovin menjadi 65 responden. Pengolahan data menggunakan alat analisis Statistical Package for Social Science (SPSS) dengan metode analisis regresi Berganda. Hasil penelitian ini menunjukan bahwa secara simultan Sikap Keuangan dan Literasi Keuangan berpengaruh terhadap Perilaku Manajemen Keuangan Pada Anggota Ghoib Community Di Kabupaten Bandung Barat. Pengaruh secara simultan ditinjukan oleh nilai fhitung > ftabel $(38.886>3,15)$. Secara parsial sikap keuangan berpengaruh terbadap sikap keuangan ditunjukan oleh nilai thitung > dari ttabel $(7,851>1,669)$ sedangkan secara parsial literasi keuangan tidak berpengaruh terbadap sikap keuangan ditunjukan oleh nilai thitung > dari ttabel < thitung $(-1,047<1,669)$. Nilai R square sebesar 0,55 menunjukan bahwa pengaruh Sikap Keuangan Dan Literasi Keuangan terhadap Perilaku Manajemen Keuangan sebesar 55\%, sedangkan sisanya $45 \%$ dipengaruhi oleh viariable lain yang tidak dimasukkan dalam penelitian ini.

Kata Kunci: Sikap Keuangan, Literasi Keuangan, Perilaku Keuangan 


\section{A. Pendahuluan}

Kecerdasan finansial dalam kehidupan modern saat ini merupakan salah satu hal yang penting. Kecerdasan finansial mencangkup upaya individu dalam mengelola keuangan dengan bijaksana untuk mencapai kesejahteraan. Terkadang individu mengalami kegagalan dalam mengelola keuangan disebabkan oleh ketidaktahuan dalam mengatur dan melakukan perencanaan pendapatan dengan bijaksana (Margaretha, 2008). Menurut (Sari, 2015)"kecerdasan finansial yang baik ditandai dengan pemahaman literasi keuangan yang tinggi".

Berdaharkan hasil penelitian yang dilakukan oleh (Annisa, 2020) menunjukkan bahwa Indonesia mendapatkan skor literasi keuangan $67 \%$ lebih baik dari pada Vietnam sebesar $64 \%$. Singapura mendapatkan skor literasi keuangan tertinggi sebesar $79 \%$ karena responden yang cukup aktif berinvestasi dan memiliki portofolio investasi yang beragam. Hong Kong dengan skor literasi keuangan $72 \%$, Filipina sebesar $71 \%$, dan Thailand sebesar $68 \%$. Skor tingkat literasi yang dihasilkan menunjukan masyarakat di Singapura dan HongKong memiliki pengetahuan yang cukup dalam melakukan pengelolaan keuangan dalam melakukan investasi dan mempertimbangkan risiko yang mungkin dihadapi.

Survei nasional literasi dan inklusi keuangan (SNLIK) yang dilakukan otoritas jasa keuangan (OJK) pada tahun 2019 menunjukkan indeks literasi keuangan mencapai 38,03\%. Angka tersebut meningkat daripada hasil survei pada tahun 2016 yaitu indeks literasi keuangan 29,7\%. Dengan demikian dalam 3 tahun terdapat peningkatan literasi keuangan masyarakat Indonesia sebesar 8,33\% (Ojk et al., 2019).

Tingkat literasi keuangan masyarakat ini dapat mempengaruhi perekonomian Indonesia, karena tingkat literasi keuangan dipengaruhi oleh keterampilan dalam mendapatkan, mengelola serta mengalokasikan sumberdaya keuangan yang dimiliki dengan lebih bijak dalam mencapai kesejahteraan. Masyarakat Indonesia masih memiliki tingkat literasi yang rendah meskipun mengalami kenaikan indeks, hal tersebut dipengaruhi oleh pengetahuan keuangan yang belum baik serta keputusan keuangan yang kurang bijaksana sehingga menimbulkan kerugian keuangan, yang menimbulkan permasalah seperti investasi bodong, kredit macet serta perilaku yang cenderung konsumtif (Sari, 2015).

Indikator untuk mengetahui tingkat kesejahteraan suatu kelompok masyarakat salah satunya kelompok petani dapat dilihat dari Nilai Tukar Petani atau NTP berdasarkan laporan bulanan data sosial ekonomi (Badan Pusat Statistik, 2020). Tingkat pertumbuhan ekonomi, tingkat pendapatan, kemakmuran, serta potensi suatu daerah dapat dilihat melalui Produk Domestik Regional Bruto atau (PDRB) dapat diketahui juga perilaku masyarakat dalam menggunakan pendapatan, apakah hanya untuk tujuan konsumsi atau juga untuk tujuan investasi. PDRB per kapita yang seringkali dipakai untuk menjelaskan tingkat kemakmuran penduduk di suatu wilayah, untuk kabupaten Bandung Barat 2020, bisa dilihat pada gambar 1 berikut:

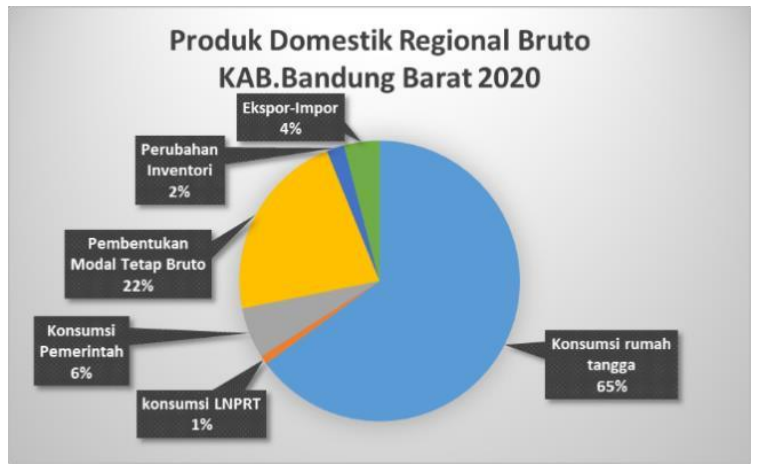

Gambar 1 Produk Domestik Regional Bruto KAB.Bandung Barat 2020

\section{Sumber : BPS KABUPATEN BANDUNG BARAT 2020}

Petani di Indonesia dalam pembentukan modal sebagian besar masih menggunakan cara menabung, yaitu menyisihkan sebagian pendapatannya dengan meningkatkan kapasitas 

produksi dengan menambah lahan dan meningkatkan tenaga kerja. Usaha tani perseorangan merupakan salah satu klasifikasi usaha tani berdasarkan bentuknya masih banyak terdapat di Indonesia. Usaha tani perseorangan memperoleh tenaga kerja melalui anggota keluarga berdasarkan gotong royong maupun upah. Pada umumnya usaha tani keluarga belum melakukan pemisahan dengan jelas pengeluaran untuk usaha tani dengan kebutuhan hidup keluarga, dengan demikian sulit untuk mengadakan analisa keuangan secara tepat. (Parimartha et al., 2014). Berdasarkan penelitian yang dilakukan oleh (Mauludin et al., 2012) bahwa kecenderungan yang ada menunjukkan bahwa peternak sebagai sebagai manajer masih belum berjalan optimal.

Pemilik dan pengelola lahan memiliki peran tersendiri dalam menjalankan usaha tani. Pengelola lahan mempunyai tanggung jawab penuh atas usaha tani yang dijalankannya baik berupa tanaman, ikan, maupun ternak. Keputusan yang bersangkutan dengan pertanian sepenuhnya berada ditangan pengelola lahan. Jadi, seorang pengelola lahan dalam menjalankan usaha tani harus mampu mengatasi dan menyelesaikan permasalahan yang timbul dalam usaha dengan mengambil keputusan yang tepat. Pengetahuan keuangan dan sikap keuangan yang baik dapat membantu para pelaku usaha dalam mengambil keputusan yang tepat dalam manajemen keuangan, sehingga menghasilkan perilaku manajemen keuangan yang baik (Humaira, 2017). Saat ini banyak komunitas berkembang di Indonesia salah satunya Komunitas Pickup bernama GHOIB yang berada di Kabupaten Bandung Barat. Berdasarkan hasil wawancara dengan ketua komunitas Pickup mayoritas anggota merupakan usia produktif yang memiliki usaha tani keluarga yang merupakan usaha secara turun temurun, mengelola lahan dengan tanaman pangan maupun peternakan hewan besar yang memiliki tingkat pendapatan yang tinggi serta melakukan mobilitas bisnis menggunakan transportasi Pickup untuk memudahkan transaksi dan pertukaran komoditas.

Berdasarkan penelitian yang dilakukan oleh (Arianti, 2020) Pelaku usaha yang memiliki pendapatan lebih tinggi akan cenderung memiliki literasi keuangan yang lebih tinggi sehingga akan cenderung memiliki kemampuan untuk merencakan dan mengelola keuangan dengan baik. Berkembangnya perilaku keuangan dipelopori oleh adanya perilaku individu dalam proses pengambilan keputusan. Perilaku keuangan yang baik mengarah pada perilaku keuangan yang bertanggungjawab sehingga seluruh keuangan baik individu maupun keluarga dapat dikelola dan dimanfaatkan dengan baik (Ida \& Dwinta, 2010). Namun disisi lain masyarakat Indonesia cenderung berpikir jangka pendek dan identik dengan praktik belanja yang cenderung konsumtif sehingga terkadang individu dengan pendapatan yang cukup masih mengalami masalah finansial karena perilaku keuangan yang kurang bijaksana (Kholilah \& Iramani, 2013).

Fenomena lain yang mempengaruhi perilaku manajemen keuangan yang dimiliki oleh para pelaku usaha tani, yaitu masalah mengenai sikap keuangan yang dimiliki. Pelaku usaha tani memiliki sikap yang berbeda mengenai keuangan, ditandai dengan beragamnya jenis modal dan sumber modal usaha tani menberikan pengaruh struktur modal dan kegiatan produksi yang berbeda. Pelaku usaha tani cenderung memiliki modal yang terbatas namun memiliki cabang usaha yang sesuai yang memberikan keuntungan tinggi terkadang saat salah memilih cabang usaha tani dapat menimbulkan risiko kegagalan serta menyebabkan kerugian.

\section{B. Metodologi Penelitian}

Penelitian ini menggunakan metode penelitian kuantitatif asosiatif. Unit analisis penelitian ini merupakan anggota GHOIB Community di Kabupaten Bandung Barat yang memiliki anggota aktif pada tahun 2020 sebanyak 185 orang.

Metode sampling yang digunakan yaitu simple random sampling. Anggota komunitas yang berpartisipasi dalam penelitian ini sebanyak 65 orang. Pengumpulan data menggunakan kuesioner/angket yang dibagikan langsung kepada responden.

Penelitian ini menggunakan Teori Perilaku Terencana (Theory of Planned Behavior) sebagai teori utama. Dalam penelitian ini terdapat satu variabel dependen yaitu perilaku keuangan (Y) dan dua variabel independen yaitu sikap keuangan (X1) dan literasi keuangan (X2), dipaparkan sebagai berikut:

\section{Teori Perilaku Terencana (Theory of Planned Behavior)}

Theory of planned behavior atau teori perilaku terencana mempengaruhi individu dalam 
berperilaku dengan cara yang menarik sikap dan norma subjektif terhadap suatu perilaku, semakin besar kontrol perilaku yang dipahami, maka semakin kuat individu dalam melakukan perilaku yang sedang dipertimbangkan. Teori perilaku yang terencana Ajzen (2005) dalam (Mahyarni, 2013)mengonsepkan perilaku sebagai hasil kombinasi sikap, norma subjektif, dan kontrol perilaku yang dirasakan. Berdasarkan uraian diatas, maka theory of planned behavior atau teori perilaku terencana (TPB) oleh Ajzen dalam (Mahyarni, 2013) digunakan sebagai pendekatan teoritis yang digunakan untuk menjelaskan variabel dependen dalam penelitian ini yaitu perilaku manajemen keuangan. Sesuai dengan teori perilaku terencana, perilaku dipengaruhi oleh sikap, norma subjektif, dan kontrol perilaku. Sikap dalam penelitian ini adalah sikap keuangan, norma subjektif dalam penelitian ini adalah gender dan pendapatan, sedangkan kontrol perilaku dalam penelitian ini adalah literasi keuangan.

\section{Perilaku Keuangan}

Perilaku manajemen keuangan merupakan kemampuan individu maupun kelompok dalam mengatur berupa serangkaian kegiatan dimulai dari perencanaan, penganggaran, pemeriksaan, pengendalian, pencarian serta penyimpanan dana keuangan untuk memenuhi kebutuhan. Perilaku manajemen keuangan hadir dari keinginan individu maupun kelompok untuk memenuhi kebutuhan sesuai dengan pendapatan yang dimiliki(Kholilah \& Iramani, 2013). Kegiatan utama dalam pengelolaan perencanaan keuangan adalah proses penganggaran dengan tujuan untuk memastikan bahwa individu mampu mengelola kewajiban keuangan secara tepat dan bijaksana dalam menggunakan pendapatan yang didapatkan (Ida \& Dwinta, 2010). Pengelolaan keuangan yang baik dilakukan untuk jangka panjang dan pendek dengan mengatur pengeluaran, memenuhi tagihan tepat waktu, merencanakan keuangan untuk masa depan dalam mencukupi kebutuhan. Perilaku manajemen keuangan menurut (Herdjiono et al., 2016) dapat dilihat dari indikator berikut ini :
a. Consumption
b. Cash-flow management
c. Saving and investment
d. Credit management

\section{Sikap Keuangan}

Menurut Eagly \& Chaiken (1993) dalam (Deyola, 2014) Sikap keuangan didefinisikan sebagai sebagai penerapan prinsip keuangan untuk mempertahankan dan menciptakan nilai dengan manajemen sumber daya dan pengambilan keputusan yang tepat. Menurut (Mien \& Thao, 2015) Sikap keuangan didefinisikan sebagai peran penting dalam menentukan perilaku keuangan. Sikap keuangan membentuk cara individu dalam menghabiskan waktu, menyimpan, dan membuang uang. Menurut Zahro (2014) dalam (Anugrah, 2018)Sikap keuangan didefinisikan sebagai keadaan pikiran, pendapat serta penilaian tentang keuangan. Sikap keuangan merupakan suatu pola kedisiplinan bagaimana individu dalam mengelola uangnya.

Sikap keuangan dapat dicerminkan oleh enam konsep berikut (Furnham, 1984) dalam (Herdjiono et al., 2016) yaitu :

1. Obsession, merujuk pada pola pikir individu maupun kelompok tentang uang dan tentang masa depan untuk mengelola uang dengan baik.

2. Power, merujuk pada individu maupun kelompok yang menggunakan uang sebagai alat untuk mengendalikan orang lain dan dapat menyelesaikan masalah.

3. Effort, merujuk pada individu maupun kelompok yang merasa pantas untuk memiliki uang sesuai dengan yang sudah dikerjakannya.

4. Inadequacy, merujuk pada individu maupun kelompok yang merasa ketidakcakapan untuk memiliki uang

5. Retention, merujuk pada individu maupun kelompok yang memiliki kecenderungan dalam menyimpan uang

6. Security, merujuk pada pandangan individu maupun kelompok yang sangat kuno tentang uang beranggapan bahwa uang lebih baik disimpan sendiri tanpa ditabung di Bank atau untuk investasi. 


\section{Literasi Keuangan}

Menurut (Otoritas Jasa Keuangan (OJK), 2017)dalam strategi nasional literasi keuangan indonesia (revisit 2017), "Literasi keuangan merupakan pengetahuan, keterampilan, dan keyakinan yang mempengaruhi sikap dan perilaku untuk meningkatkan kualitas pengambilan keputusan dan pengelolaan keuangan dalam rangka mencapai kesejahteraan”.

Menurut (Lusardi dan Tufano; 2008) dalam (Herdjiono et al., 2016) literasi keuangan didefinisikan "Sebagai kemampuan untuk membuat keputusan sederhana mengenai kontrak utang, khususnya bagaimana menerapkan pengetahuan dasar tentang bunga, diukur dalam konteks pilihan keuangan sehari-hari".

Menurut Chen dan Volpe (1998) literasi keuangan didefinisikan "Pengetahuan untuk mengelola keuangan dalam pengambilan keputusan keuangan. Pengetahuan keuangan meliputi pengetahuan umum keuangan pribadi kemampuan seseorang dalam mengelola aset keuangan pribadi. Dengan menerapkan cara mengelola keuangan yang benar maka seseorang akan mampu memanfaatkan uang yang dimilikinya untuk mencapai tujuan investasi asuransi tabungan maupun pinjaman." Menurut Lusardi dalam (Anggraeni \& Tandika, 2019) literasi keuangan mencakup 4 (empat) konsep keuangan, yaitu :

1. Pengetahuan Dasar Mengenai Keuangan Pribadi (General Personal Finance Knowledge)

2. Pengetahuan Mengenai Menabung dan Meminjam (Saving and borrowing)

3. Pengetahuan mengenai Asuransi (Insurance)

4. Pengetahuan mengenai Investasi (Investment)

\section{Pendapatan}

Menurut Kamus Besar Bahasa Indonesia, pendapatan merupakan sesuatu yang diadakan, dibuat, dan dijadikan usaha. Kamus Ekonomi mendefinisikan pendapatan merupakan uang yang diterima oleh seseorang dalam perusahaan dalam bentuk gaji, upah, sewa, bunga, maupun laba.. Pengeluaran keluraga tidak akan sama besarnya, karena dari waktu ke waktu akan terus berkembang tergantung dari faktor seperti jumlah penghasilan, besarnya keluarga, tingkat kebutuhan, taraf pendidikan dan status sosialnya, kebijaksanaan dalam mengelola keuangan. Menurut (Badan Pusat Statistik, 2020) tingkat pendapatan dapat dikelompokkan menjadi empat golongan yaitu:

a. Golongan sangat tinggi : lebih dari Rp. 4.000.000,00 per bulan

b. Golongan tinggi : Rp. $3 \cdot 100.000,00 \mathrm{~s} / \mathrm{d}$ Rp. $4.000 .000,00$

c. Golongan sedang : Rp. 2.100.000,00 s/d Rp. 3.000.000,00

d. Golongan rendah: Rp. 1.100.000,00 s/d Rp. 2.000.000,00

e. Golongan sangat rendah : kurang dari Rp. $1.000 .000,00$ per bulan.

Skala pengukuran yang digunakan dalam penelitian ini adalah skala likert 1 sampai 5 yaitu 1 (Sangat Tidak Setuju), 2 (Setuju), 3(Ragu), 4(Setuju), 5(Sangat Setuju).

Teknik analisis yang digunakan untuk mengukur hubungan antar variabel dependen dan independen menggunakan analisis regresi linear berganda. Hubungan antar variabel dapat digambarkan sebagai berikut :

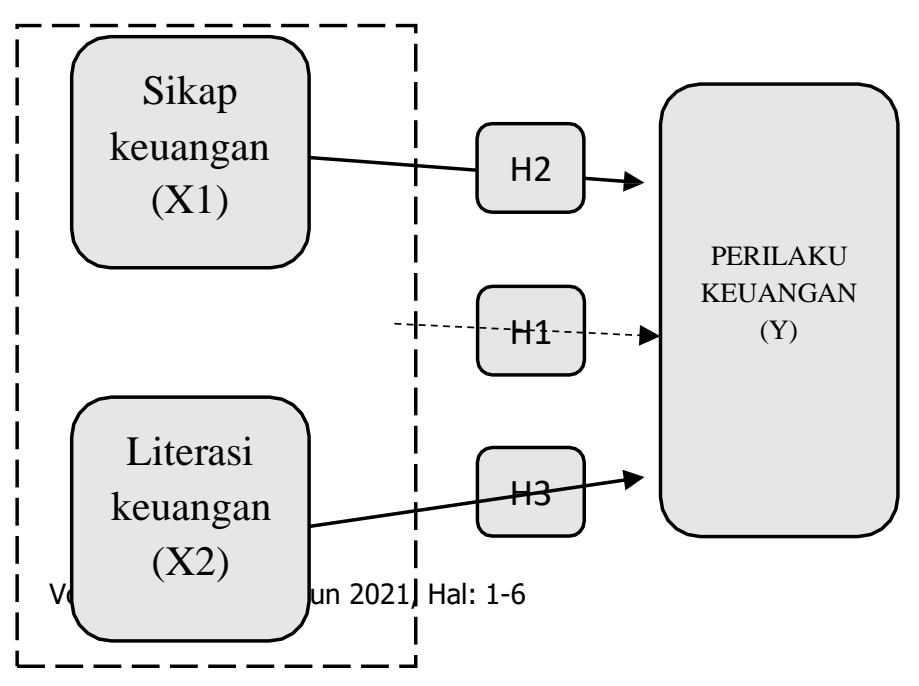


Gambar 2. Hubungan antar variabel

Berdasarkan model penelitian di atas, menggunakan persamaan sebagai berikut :

$Y=a+b_{1} X_{1}+b_{2} X_{2}+e$

Keterangan:

$\mathrm{Y}=$ Perilaku Manajemen Keuangan

$\mathrm{X} 1=$ Sikap Keuangan

$\mathrm{X} 2$ = Literasi Keuangan

\section{Pembahasan dan Diskusi}

\section{Analisis Deskriptif}

Tabel 1. Hasil Analisis Deskriptif

\begin{tabular}{|l|l|l|l|}
\hline No & Variabel & Persentase & Kategori \\
\hline 1. & $\begin{array}{l}\text { Perilaku } \\
\text { Keuangan }\end{array}$ & $\mathbf{7 7 \%}$ & Tinggi \\
\hline 2. & $\begin{array}{l}\text { Sikap } \\
\text { Keuangan }\end{array}$ & $\mathbf{7 1 \%}$ & Tinggi \\
\hline 3. & $\begin{array}{l}\text { Literasi } \\
\text { Keuangan }\end{array}$ & $\mathbf{7 8 \%}$ & Tinggi \\
\hline
\end{tabular}

Sumber: Data Primer Diolah 2021

Berdasarkan tabel 1. Menunjukan bahwa persentase variabel perilaku keuangan sebesar 77\%, sehingga tersebut menyatakan bahwa perilaku keuangan dalam kategori tinggi. Hal tersebut menyatakan bahwa responden mampu mengelola asset keuangan dengan bijaksana. Hasil persentase variabel sikap keuangan sebesar $71 \%$. Hal tersebut menyatakan bahwa sikap keuangan dalam kategori tinggi. Hasil persentase variabel literasi keuangan sebesar $78 \%$. Hal tersebut menyatakan bahwa sikap keuangan dalam kategori tinggi.

\section{Analisis Regresi Linear Berganda}

Tabel 2. Hasil Regresi Linear Berganda

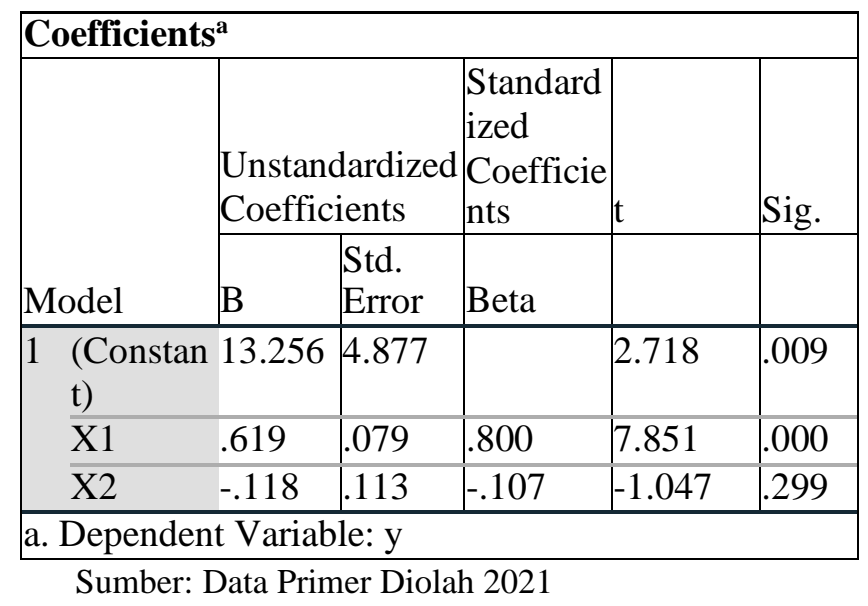

Berdasarkan hasil pengolahan data primer pada tabel 2 di atas dapat dirumuskan model persamaan regresi linear berganda sebagai berikut :

$Y=13,256+0,619 X_{1}+\left(-0,118 X_{2}\right)+e$

Berdasarkan persamaan diatas, maka dapat diinterpretasikan sebagai berikut: 
a. Nilai konstanta sebesar 13,256 artinya apabila variabel sikap keuangan dan literasi keuangan $=0$, maka pengaruhnya terhadap perilaku keuangan anggota komunitas Ghoib adalah sebesar 13,256.

b. $\quad b_{1} X_{1}=0,619$ artinya setiap perubahan atau kenaikan pada variabel sikap keuangan sebesar 1 satuan maka pengaruhnya terhadap perilaku keuangan anggota komunitas Ghoib adalah sebesar0,619dengan asumsi variabel x1 dan x2.

c. $b_{2} X_{2}=-0,118$ artinya setiap perubahan pada variabel literasi keuangan sebesar 1 satuan, maka pengaruhnya terhadap perilaku keuangan anggota komunitas Ghoib adalah sebesar-0,118 dengan asumsi variabel $\mathrm{x} 1$ dan $\mathrm{x} 2$.

\section{Uji Hipotesis}

\section{Pengujian Hipotesis Parsial (Uji t)}

Uji hipotesis parsial dilakukan untuk melihat sejauh mana pengaruh dari variabel independen secara individual dalam memengaruhi atau menjelaskan variabel dependen

Hipotesis

H01 $={ }_{\beta} 1=0$, Tidak terdapat Pengaruh antara Sikap Keuangan (X1) terhadap Perilaku Keuangan (Y)

Ha1 $=_{\beta} 1 \neq 0$, Terdapat Pengaruh antara Sikap Keuangan (X1) terhadap Perilaku Keuangan (Y). $\mathrm{H} 02={ }^{2}=0$, Tidak terdapat Pengaruh antara Literasi Keuangan (X2) terhadap Perilaku Keuangan (Y)

Ha2 $={ }_{\beta} 2 \mathrm{z} \neq 0$, Terdapat Pengaruh antara Literasi Keuangan (X2) terhadap Perilaku Keuangan (Y).

Menentukan nilai Ttabel dapat dilihat pada tabel statistik untuk signifikansi 0,05, $d F=(n-k)$. Jadi, $F 2=(65-3)=62$. Hasil diperoleh untuk Ttabel sebesar 1,669. Berdasarkan tabel 2 hasil regresi lenear berganda dapat disimpulkan sebagai berikut :

a. Variable sikap keuangan memiliki nilai thitung sebesar 7,851 maka nilai thitung lebih besar daripada nilai ttabel $(7,851>1,669)$. Berdasarkan hasil uji hipotesis tersebut dapat disimpulkan bahwa nilai Thitung > Ttabel , H01 ditolak dan Ha1 diterima, jadi dapat disimpulkan bahwa Terdapat Pengaruh positif secara parsial antara Sikap Keuangan (X1) terhadap Perilaku Keuangan (Y).

b. Variable literasi keuangan memiliki nilai thitung sebesar -1,047 maka thitung lebih kecil daripada nilai ttabel $(-1,047<1,669)$. Berdasarkan hasil uji hipotesis tersebut dapat disimpulkan bahwa nilai Thitung $<$ Ttabel, H02 diterima dan Ha2 ditolak maka, Tidak terdapat Pengaruh secara parsial antara Literasi Keuangan (X2) terhadap Perilaku Keuangan (Y).

\section{Pengujian Hipotesis Simultan (Uji-F)}

Uji hipotesis simultan dilakukan untuk melihat apakah semua variabel bebas atau variabel independen yang ada dalam model memiliki pengaruh yang secara bersama-sama terhadap variabel terkait atau variabel dependen.

Hipotesis

H0 : Tidak terdapat Pengaruh antara Sikap Keuangan (X1) dan Literasi Keuangan (X2) terhadap Perilaku Keuangan (Y)

Ha : Terdapat Pengaruh antara Sikap Keuangan (X1) dan Literasi Keuangan (X2) terhadap Perilaku Keuangan (Y).

Tabel 3. Hasil Uji F

\begin{tabular}{|l|c|c|c|c|c|c|}
\hline \multicolumn{7}{|c|}{ ANOVA $^{\mathrm{a}}$} \\
\hline & & Sum of & & \multicolumn{1}{c|}{ Mean } \\
Model & Squares & df & Square & F & Sig. \\
\hline \multirow{2}{*}{1} & Regression & 1241.126 & 2 & 620.563 & 38.886 & $.000^{\mathrm{b}}$ \\
\cline { 2 - 7 } & Residual & 989.428 & 62 & 15.959 & & \\
\hline
\end{tabular}




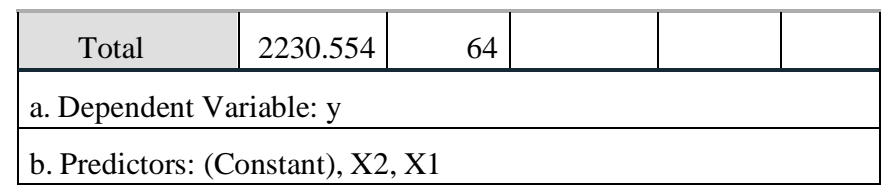

Sumber: Data Primer Diolah 2021

Menentukan nilai Ftabel dapat dilihat pada tabel statistik untuk signifikansi 0,05 dengan $d F 1=$ $(k-1)$ dan $d F 2=(n-k)$. Jadi, $d F 1=(3-1)=2$ atau $d F 2=(65-3)=62$. Hasil diperoleh untuk Ftabel sebesar 3,15. Berdasarkan tabel 3. Hasil uji-f diperoleh Fhitung > Ftabel (38.886 $>3,15$ ) dengan nilai sig $0,000<0,05$ maka H0 ditolak. Sehingga dapat disimpulkan bahwa Terdapat Pengaruh positif antara Sikap Keuangan (X1) dan Literasi Keuangan (X2) terhadap Perilaku Keuangan (Y).

\section{Pengujian Koefisien Determinasi (R2)}

Koefisien determinasi atau R'Square (R2) bertujuan untuk mengukur seberapa besar variabel independen mempengaruhi variabel dependen.

Tabel 4. Hasil Uji Koefisien Determinasi (R2)

\begin{tabular}{|l|c|r|r|r|}
\hline \multicolumn{5}{|l|}{ Model Summary $^{\mathbf{b}}$} \\
\hline $\begin{array}{l}\text { Mode } \\
1\end{array}$ & $\mathrm{R}$ & R Square & $\begin{array}{c}\text { Adjusted R } \\
\text { Square }\end{array}$ & $\begin{array}{c}\text { Std. Error of } \\
\text { the Estimate }\end{array}$ \\
\hline 1 & $.746^{\mathrm{a}}$ & .556 & .542 & 3.995 \\
\hline \multicolumn{5}{|l}{} \\
a. Predictors: (Constant), X2, X1 \\
b. Dependent Variable: y \\
Sumber: Data Primer Diolah 2021
\end{tabular}

Berdasarkan tabel 4. Hasil Uji Koefisien Determinasi $\left(\mathrm{R}^{2}\right)$ memperoleh nilai $R$ Square sebesar 0,556. Hal ini menunjukkan bahwa Perilaku Keuangan pada anggota komunitas dipengaruhi oleh variabel Sikap Keuangan dan Literasi Keuangan sebesar 55,6\%, sedangkan sisanya sebesar $44,4 \%$ dipengaruhi oleh faktor lain yang tidak termasuk dalam penelitian ini.

\section{Kesimpulan}

Berdasarkan hasil penelitian kepada anggota GHOIB Community di Kabupaten Bandung Barat untuk mengetahui Pengaruh Sikap Keuangan dan Literasi Keuangan terhadap Perilaku Manajemen Keuangan, ditarik kesimpulan sebagai berikut :

1. Terdapat pengaruh positif Sikap Keuangan dan Literasi Keuangan secara simultan terhadap Perilaku Manajemen Keuangan pada pada anggota GHOIB Community di Kabupaten Bandung Barat.

2. Terdapat pengaruh positif Sikap Keuangan terhadap Perilaku Manajemen Keuangan Pada Anggota GHOIB Community di Kabupaten Bandung Barat.

3. Tidak Terdapat pengaruh Literasi Keuangan terhadap Perilaku Manajemen Keuangan Pada Anggota GHOIB Community di Kabupaten Bandung Barat.

\section{Daftar Pustaka}

[1] Anggraeni, aprilia aldiya, \& Tandika, D. (2019). Pengaruh Financial Literacy dan Financial Attitude terhadap Financial Management Behavior. Prosiding Manajemen, 5 no.1, 85-92.

[2] Annisa. (2020). Cek Skor Literasi Keuangan Indonesia di 2020. Go Bear. https://www.gobear.com/id/blog/personal-finance/yuk-cek-skor-literasikeuangan-indonesia-di-2020

[3] Anugrah, R. (2018). PENGARUH LITERASI KEUANGAN DAN SIKAP KEUANGAN TERHADAP PERILAKU PENGELOLAAN KEUANGAN MASYARAKAT DENGAN NIAT SEBAGAI VARIABEL INTERVENING SKRIPSI. In Fakultas Ekonomi dan Bisnis Islam UIN Alauddin Makassar. 
http://dx.doi.org/10.1053/j.gastro.2014.05.023\%0Ahttps://doi.org/10.1016/j.gie.2 018.04.013\%0Ahttp://www.ncbi.nlm.nih.gov/pubmed/29451164\%0Ahttp://www .pubmedcentral.nih.gov/articlerender.fcgi?artid=PMC5838726\%250Ahttp://dx.d oi.org/10.1016/j.gie.2013.07.022

[4] Badan Pusat Statistik. (2020). Laporan Bulanan Data Sosial Ekonomi (2020th ed.). Badan Pusat Statistik.

[5] Deyola, Y. (2014). Pengaruh Pengetahuan Keuangan dan Sikap Keuangan terhadap Keputusan Menabung pada Produk Tabungan di Perbankan (Studi pada Mahasiswa Program Studi Manajemen FPEB UPI Bandung Angkatan 20102013). Universitas Pendidikan Indonesia.

[6] Herdjiono, I., Damanik, L. A., \& Musamus, U. (2016). Pengaruh Financial attitude, Financial Knowledge, Parental Income Terhadap Financial Managemen. Manajemen Teori Dan Terapan, 1(3), 226-241.

[7] Humaira, I. (2017). Pengaruh Pengetahuan Keuangan, Sikap Keuangan Dan Kepribadian Terhadap Perilaku Manajemen Keuangan Pada Pelaku Umkm Sentra Kerajinan Batik. Skripsi Universitas Negeri Yogyakarta, 129-132. http://dx.doi.org/10.1016/j.biotechadv.2010.07.003\%0Ahttp://dx.doi.org/10.1016 /j.scitotenv.2016.06.080\%0Ahttp://dx.doi.org/10.1016/j.bbapap.2013.06.007\%0 Ahttps://www.frontiersin.org/article/10.3389/fmicb.2018.02309/full\%0Ahttp://d x.doi.org/10.1007/s13762-

[8] Ida, \& Dwinta, C. Y. (2010). PENGARUH LOCUS OF CONTROL , FINANCIAL KNOWLEDGE , INCOME TERHADAP FINANCIAL MANAGEMENT BEHAVIOR. 12(3), 131-144.

[9] Kholilah, N. Al, \& Iramani, R. (2013). Studi Financial Management Behavior Pada Masyarakat Surabaya. Journal of Business and Banking, 3(1), 69. https://doi.org/10.14414/jbb.v3i1.255

[10] Mahyarni. (2013). THEORY OF REASONED ACTION DAN THEORY OF PLANNED BEHAVIOR (Sebuah Kajian Historis tentang Perilaku). Jurnal ELRIYASAH, 4(1), 13. https://doi.org/10.24014/jel.v4i1.17

[11] Margaretha, F. (2008). PERAN KECERDASAN FINANSIAL DALAM MENINGKATKAN KESEJAHTERAAN DAN EKONOMI RAKYAT INDONESIA. Jurnal Ilmiah Manajemen Bisnis, 8(April), 131-144.

[12] Mauludin, M. A., Winaryanto, S., Alim, S., \& Metode, M. (2012). Peran Kelompok dalam Mengembangkan Keberdayaan Peternak Sapi Potong ( Kasus Di Wilayah Selatan Kabupaten Tasikmalaya ) Role of the Group in Developing Beef Cattle Farmers Empowerment ( A Case Study in Tasikmalaya South Region of Kabupaten Tasikmalaya ). Jurnal Ilmu Ternak, 12(1), 1-8.

[13] Ojk, S., Literasi, I., Inklusi, D. A. N., \& Meningkat, K. (2019). Sp 58/dhms/ojk/xi/2019. November, 29600000.

[14] Otoritas Jasa Keuangan (OJK). (2017). STRATEGI NASIONAL LITERASI KEUANGAN INDONESIA ( Revisit 2017).

[15] Parimartha, K. W., Sukanata, I. W., Suciani, Putri, B. R. T., Kayana, I. G. N., \& Budiartha, I. W. (2014). ILMU USAHA TERNAK DAN KOPERASI ( SUB POKOK BAHASAN : KLASSIFIKASI USAHA TANI , UNSUR-UNSUR POKOK USAHA TANI ) Ir . Ketut Warsa Parimartha, MP. In DIKTAT (p. 30). PROGRAM STUDI PETERNAKAN FAKULTAS PETERNAKAN UNIVERSITAS UDAYANA.

[16] Sari, D. A. (2015). Financial Literacy .....( Dian Anita Sari). 01(02), 171-189. 